\title{
Identification of IT-Needs to Cope with Dynamism in Collaborative Networked Organizations-A Case Study
}

Citation for published version (APA):

van den Heuvel, R., van de Wetering, R., Bos, R., \& Trienekens, J. J. M. (2020). Identification of IT-Needs to Cope with Dynamism in Collaborative Networked Organizations-A Case Study. In R. Agrifoglio, R. Lamboglia, D. Mancini, \& F. Ricciardi (Eds.), Digital Business Transformation: Organizing, Managing and Controlling in the Information Age (pp. 219-236). Springer Nature Switzerland AG. Lecture Notes in Information Systems and Organisation Vol. 38 https://doi.org/10.1007/978-3-030-47355-6_15

\section{DOI:}

10.1007/978-3-030-47355-6_15

Document status and date:

Published: 01/01/2020

Document Version:

Publisher's PDF, also known as Version of record

\section{Document license:}

\section{Taverne}

Please check the document version of this publication:

- A submitted manuscript is the version of the article upon submission and before peer-review. There can be important differences between the submitted version and the official published version of record. People interested in the research are advised to contact the author for the final version of the publication, or visit the DOI to the publisher's website.

- The final author version and the galley proof are versions of the publication after peer review.

- The final published version features the final layout of the paper including the volume, issue and page numbers.

Link to publication

\section{General rights}

Copyright and moral rights for the publications made accessible in the public portal are retained by the authors and/or other copyright owners and it is a condition of accessing publications that users recognise and abide by the legal requirements associated with these rights.

- Users may download and print one copy of any publication from the public portal for the purpose of private study or research.

- You may not further distribute the material or use it for any profit-making activity or commercial gain

- You may freely distribute the URL identifying the publication in the public portal.

If the publication is distributed under the terms of Article 25fa of the Dutch Copyright Act, indicated by the "Taverne" license above, please follow below link for the End User Agreement:

https://www.ou.nl/taverne-agreement

Take down policy

If you believe that this document breaches copyright please contact us at:

pure-support@ou.nl

providing details and we will investigate your claim.

Downloaded from https://research.ou.nl/ on date: 26 Apr. 2023 


\title{
Identification of IT-Needs to Cope with Dynamism in Collaborative Networked Organizations - a Case Study
}

\author{
Ronald van den Heuvel $^{1}$, Rogier van de Wetering ${ }^{1}$, Rik Bos ${ }^{1}$, Jos Trienekens ${ }^{1}$ \\ ${ }^{1}$ Faculty of Management, Science and Technology, \\ Open University of the Netherlands, Heerlen, The Netherlands \\ [ronald.vandenheuvel, rogier.vandewetering, rik.bos, \\ jos.trienekens ] @ou.nl
}

\begin{abstract}
Collaborative Networked Organizations (CNOs) are increasingly common in current dynamic markets. The participants in a CNO try to achieve a common goal while acting on market opportunities. Information technology (IT) facilitates collaboration between participants within a CNO. In this paper, we show how CNOs cope with network-dynamics related to their IT-needs. Two sub-characteristics of network dynamics, respectively many-to-many relations and interaction patterns, will be investigated. In the end, we are trying to answer the question regarding what IT-needs CNOs have, to cope with CNO-dynamism. Based on a literature review we developed a framework on CNO-dynamism and executed a multi-case study within four CNOs. We conclude that all framework components are recognized within the CNOs. CNOs appeared to mainly cope with dynamics by using collaborative platforms, task management systems, and conference facilities.
\end{abstract}

Keywords: Collaborative Networked Organizations (CNOs), CNO-dynamism, IT-needs, IT-alignment, Multiple case study.

\section{Introduction}

Organizations that operate in highly turbulent markets demand more agility from their strategic partners and suppliers. In response to rapidly changing customer demands and wishes, organizations are forced to collaborate and jointly create products and services [1]. Collaborative networks $(\mathrm{CN})$ have become a common organizational form in these dynamic markets to innovate and collaborate, allowing these organizations to cope with the dynamics at hand. A collaborative networked organization $(\mathrm{CNO})$ is comprised of multiple participants whose aim is to achieve common goals [1-3]. Achieving a state of Business/IT-Alignment (BITA) between the participants in the CNO appears to be a valuable endeavor that could provide benefits on agility and performance [4].

Extant literature on BITA predominantly focuses on uni-minded organizations (as opposed to networked organizations); it does not consider the networked dynamics "lens" [4-7]. The alignment frameworks dedicated to uni-minded organizations are based on hierarchical structures and governed within one organization. Within a CNO, multiple, participating organizations have their own governance structures. BITA could 
provide organizational benefits to these CNOs. It is this networked perspective on alignment within CNOs that is unique to the current dynamic times; this perspective is not yet part of the current body-of-knowledge.

The goal of this paper is to provide insight into the need for IT systems (described as IT-needs) to overcome or react to (described as coping with) the network-dynamics that a $\mathrm{CNO}$ encounters. This CNO-dynamism influences the $\mathrm{CNO}$ via market dynamics, network dynamics between partners and dynamics related to reconfigurations of the $\mathrm{CNO}$ itself. This results in our research question:

RQ: What IT-needs do CNOs have to cope with CNO-dynamism?

To answer this research question, we use the "Dynamic and self-regulating networks" characteristic presented by Van den Heuvel, Trienekens, Van de Wetering, and Bos [8] and focus, as part of this characteristic, on the interrelations and interactions between participants within the CNO. We focus on two operational (system/process) characteristics: "many-to-many relations" and "interaction patterns." Many-to-many relations and interaction patterns are typical for collaborative environments, where multiple organizations work together.

Via a systematic literature review (SLR) we created a framework to structurally gather results in the case study. The case study consists of 15 interviews over 12 organizations that participate in the CNOs. Semi-structured interviews were used to gather insight into IT-needs, and the results were transcribed and coded to answer the research question.

Our results can help practitioners to determine the needed IT when creating a CNO to can cope with dynamism. Researchers can use our results to get a better insight into these IT-needs to extent BITA models that fit CNOs and their dynamics.

Section 2 describes the theoretical background. Section 3 describes the methodology of the SLR, framework development, the case study, and coding. Section 4 describes the framework that is used within the case study. Section 5 outlines the results. We finalize this paper with a discussion (section 6) and a conclusion (section 7).

\section{Theoretical Background}

\subsection{Networked Organizational Context}

CNs are complex networks of organizations that cannot achieve their goals by themselves. These CNs are not hierarchically structured, are evolutionary, and are continuously interacting with the environment [9]. When we talk about organized collaboration, the term Collaborative Networked Organization (CNO) is used [10].

Walters and Buchanan [9] describe that these organizations have benefits compared to hierarchical networks. A few of the benefits are: leverage via best capabilities, higher speed due to reduced management and increased IT usage, agility, independence, and interdependence [9]. The rationale behind "increased IT usage" within a CNO is that CNOs need to communicate and IT is needed to facilitate this communication $[10,11]$. 


\subsection{Business/IT-Alignment (BITA)}

BITA has been popularized by Henderson and Venkatraman [12] in the Strategic Alignment Model (SAM). Henderson and Venkatraman [12] state that "the inability to realize value from IT investments is, in part, due to the lack of alignment between the business and I/T strategies of organizations." Organizations should embrace a process of continuous adaptation and change in order to achieve alignment. BITA "refers to applying Information Technology (IT) in an appropriate and timely way, in harmony with business strategies, goals and needs" [13] and leads to an increase in agility and performance [4]. Within this paper, we define alignment as strategic and operational alignment as described by Bagheri, Kusters, and Trienekens [14], where strategic alignment is the fit between business strategy and IT strategy and operational alignment is the alignment between business processes and supportive information systems.

The extant literature shows that a higher degree of alignment within an organization provides benefits to the firm [4]. Current models for BITA do not address the 'networked lens' that we see within a collaborative environment [8].

\subsection{Many-to-Many Relations}

CNOs are networks of participating entities, where entities can be a variety of types like organizations, humans, or systems. An important aspect is the bi-directional, reciprocal way of exchanging resources [15] which show bi-directional interaction existing between participants in a CNO. If we consider the dynamics of a $\mathrm{CNO}$ and the vast number of participants collaborating within the $\mathrm{CNO}$, many relations can exist. Each participant and organization can take part in multiple other organizations, resulting in many-to-many relations which could have an epistatic nature.

Ahuja [16] argues that the number of relations, specifically direct ones, can positively affect the innovative output of the organization. The relationships influence the output via knowledge sharing, complementarity, and scale. The power of relations and their impact on the innovative output is essential for the dynamism that CNOs experience. While the benefits of indirect relations are low compared to direct relations, they still contribute to innovative power.

\subsection{Interaction Patterns}

The created interaction patterns are the connections between the entities during collaboration. Jaakkola, Henno, Thalheim, and Mäkelä [17] describe collaboration in Information Systems (IS) research as information processing by humans and computers, the information transfer between them and the transformations needed in the transfer itself. Camarinha-Matos [18] describes collaboration as "a more demanding process in which entities share information, resources, and responsibilities to jointly plan, implement, and evaluate a program of activities to achieve a common goal and therefore jointly generating value." Entities can manifest in various forms, such as organizations, humans, and systems. 
Dynamism in CNOs, whether it is facilitated by internal or external change, forces collaboration to evolve and thus results in ever-changing interaction patterns. These internal or external interaction patterns need to be taken into account when looking at CNO-dynamism as a whole [19].

\section{$3 \quad$ Research Methodology}

Our research comprises a literature review (3.1) that forms the basis for our framework (3.2) used in the case study (3.3), which is executed via interviews. The interviews were transcribed and coded (3.4) to gather insights into IT-needs (see Fig. 1).

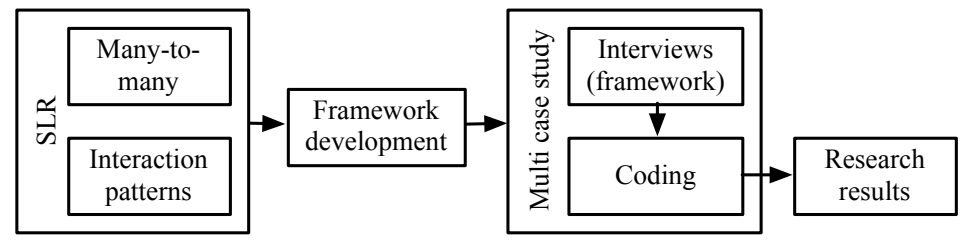

Fig. 1. Research model

\subsection{Literature Review}

Two SLRs were conducted for each of the sub-characteristics. The execution was based on Saunders, Lewis, and Thornhill [20]. We selected articles based on the following characteristics: peer-reviewed, age (10 years, or seminal paper), language (English). The search query was based on the components CNO, BITA, dynamic and self-regulating network (DSN) extended with the sub-characteristic interaction patterns (IP) or many-to-many (MM) relations. We executed the search by combining the mentioned components to create search queries executed on EBSCO host (Academic Search Elite, Business Source Premier and E-journals). Additional literature was gathered by using backward searching. The literature found during the review was analyzed and used to create the framework (see Table 1 and Table 2).

Table 1. Results SLR on many-to-many sub-characteristic

\begin{tabular}{lr}
\hline Building blocks & Results \\
\hline CNO + BITA + MM & 73 \\
\hline CNO + BITA + Dynamics + MM & 28 \\
\hline CNO + BITA + Self-regulating + MM & 1 \\
\hline CNO + BITA + Dynamics + Self-regulating + MM & 0 \\
\hline
\end{tabular}

Table 2. Results SLR on interaction patterns sub-characteristic

\begin{tabular}{lr}
\hline Building blocks & Results \\
\hline CNO + IP & 4 \\
\hline BITA + IP & 1 \\
\hline DSN + IP & 19 \\
\hline CNO + DSN + IP & 0 \\
\hline
\end{tabular}




\subsection{Framework Development}

The material from the SLRs was reviewed and analyzed to create the framework that was used during the case study interviews. The framework components were grouped into themes. Section 4 contains the framework, based on the theme CNO, relation (many-to-many relations), and interaction (interaction patterns).

\subsection{Case Study Approach}

The selection of organizations is based on heterogenous non-probability sampling advised by Saunders et al. [20]. Organizations needed to meet the following qualifications: The CNO is operational or has been in the last six months; A clear goal for the collaboration is available; At least one IT specialist and one business specialist are available for the semi-structured interviews within the $\mathrm{CNO}$; Collaboration exists between three or more partners (to account for many-to-many relations); Within the case study, a minimum of three interviews are executed within a CNO. If the requirements could not be met, the case would be discarded. We aimed at four organizations within the same sector with goals related to IT service management (ITSM).

The interviews were held in a semi-structured manner based on the framework and an interview guide. The semi-structured interview provided us with the flexibility to discuss specific topics within the interview guide. Specifically, experiences were asked within the interview to focus on real effects instead of expected outcomes. A trial interview was held to test the interview guide. The participant received an introduction letter to increase the understanding of the research topic and to level the knowledge between the participants within the study. Interviews were conducted face-to-face, recorded, and transcribed. The transcriptions were provided to the participant for validation [20]. All transcripts are anonymized to provide confidentiality and anonymity.

\subsection{Coding Procedure}

Quantitative coding was used to analyze the transcripts of the interviews inspired by the methods of Muhr [21]. Closed-coding was used to set a base codebook, based on the interview guide, that was used by all three researchers. Each researcher independently coded and used open-coding to extend the codebook. Codes that were created during the coding process were shared within the research team to align coded phenomena. After closed and open-coding we used axial coding to find relations between the codes.

The first author reevaluated the codes in the transcripts. An independent researcher evaluated the process and, via selective bi-directional inter-coding, validated the coded interviews based on the transcribed text and codes. We retrieved an inter-coder agreement beyond $90 \%$ of these transcripts, providing us with sufficient confidence in our analysis [22]. 


\section{$4 \quad$ Network Dynamics Framework}

The framework created from the literature review contains three main themes. The first theme is $\mathrm{CNO}$, which provides insight into CNO-related characteristics to classify the CNOs and topology. The second theme is the relation, which provides insight into the connection between participants within the network. The third theme is interaction, which provides insight into the relation itself. The first theme is descriptive for the CNO the second and third are possible influencers of CNO-dynamism.

\subsection{Theme CNO}

There are multiple forms of CNOs structured in the taxonomy provided by CamarinhaMatos and Afsarmanesh [23], and this taxonomy is still evolving.

Based on the SLR, we found the following components related to the theme "CNO": $\mathrm{CNO}$ goal, $\mathrm{CNO}$ type, and CNO life cycle. Cheikhrouhou, Pouly, and Madinabeitia [24] describe two topologies of networks - vertical and horizontal. We called this CNO Type, where vertical CNOs try to extend their capabilities and horizontal CNOs try to extend their capacity to fulfill a business goal. Camarinha-Matos and Afsarmanesh [25] describe five stages of the life cycle of the CNO: L1 Creation: In this phase, the CNO and its components are created or acquired, and the legal structure is formed; L2 Operation: $\mathrm{CNO}$ is operational and moving towards its intended goal; L3 Evolution: In this phase, the CNO is changed in daily operation. L4 Dissolution: In this phase, the CNO is ended, commonly when they achieve their goal. This phase is common for short-term CNOs; L5 Metamorphosis: The CNO fundamentally changes its goal or structure. This stage is common for long-term partnerships where the L4 is too destructive for the assets that are available within the $\mathrm{CNO}$.

These CNO-related components provide insight into the $\mathrm{CNO}$ and could potentially identify relations between $\mathrm{CNO}$-components, and the dynamics related components many-to-many and interaction patterns.

\subsection{Theme Relation (Many-to-Many Relations)}

Based on the SLR, we found the following components related to the theme "relation": trust, entity role, relation type, tie form, tie strength, and embeddedness.

Cheikhrouhou et al. [24] mention five types of trust in their paper: competence, contractual, relational, indirect, and negative trust. Cheikhrouhou et al. [24] define these types of trust as: Competence trust is founded by the belief a partner has the competence to achieve the goals. Contractual trust is based on economic or "formal" aspects of a relationship. Relational trust includes human aspects of the economic relations that could allow developing or improving relations while indirect trust focuses on the external factors and components that can indirectly influence trust between partners in a CNO. Last, we have negative trust, defined as the difference of power between two partners in a considered relation. "If the relation is not on the same level from the point of view of both companies, this can lead to a source of conflict between the partners" [24]. 
Grefen et al. [1] describe two non-hierarchical types of entity roles within a network: hub, a focal firm distributing communications through the network, and contact point, a focal firm acting as a contact point to a client party for accepting orders and distributing them through the network [1].

A connection between two or more actors in the network results in interdependency $[16,26]$. Ahuja [16] describes three relation types: direct ties - the arrangement of direct inter-firm linkages between a firm and its network partners, which primarily serves as sources for resources, and information. Indirect ties - inter-firm linkages between a firm and its indirect partners, via partners of its partners, which primarily serves as a source for information. Structural holes - a structural hole is a gap between parties that have a relationship with a central organization but not with each other, resulting in the possibility of receiving different information within the network [16]

Wulf and Butel [27] found that the position of a participant in the network influences their ability to achieve sustainable competitive advantage (tie form). They describe a difference between business eco-systems and business networks. In these two constellations, the structure is viewed from a governance and a relationship point of view. The governance point of view relates to the CNO. The structural part describes the difference between formal and informal ties. Formal ties are related to hierarchical structures governed by contracts (prescribed) or ownership, whereas informal ties are related to social organizational structures where there are informal relationships between individuals and are the basis for collaboration and knowledge transfer (emergent) [28].

When communication takes place mutually and frequently, strong ties exist [27]. They can reduce cost, reduce monitoring and integration costs, and improve information flow. Thus strong cohesion can be instigated [29]. "Weak ties provide access to non-redundant information" [30]. Strong ties and weak ties are part of the framework where the "strongness" relates to frequent mutual interaction and infrequent distant interaction (tie strength).

Osman [26] studied the influence of formal versus informal ties to the embeddedness of the participant within the CNO. Embeddedness is the degree of centrality of any company within the social network. Strong embeddedness refers to an organization which has many close ties with which it is in frequent contact, it may be the hub with many spokes; weak embeddedness is where the organization does not actively take part in ties within the (social) network.

These components provide the ability to gather data about the relations within the $\mathrm{CNO}$, related to dynamics and how IT-needs change based on these relations.

\subsection{Theme Interaction (Interaction Patterns)}

In the theme "interaction" we identified interaction mode, locale, time, the goal of the interaction, structures, and level of formality as relevant components. These components describe how a relation is used. We will describe the components in the following text.

The modes as described by Oukes and Raesfeld von [31] are as follows: Interaction create mode: "The creation of innovative solutions by an organization and its counterpart beyond the scope of their initial agreement to align their interests and preserve the 
relationship"; Interaction acquiesce mode: "The compliance of an organization to the action of its counterpart or situation even at the expense of its own short-term interests"; Interaction compromise mode: "The partial compliance of an organization to the action of its counterpart or situation. They renegotiate the relationship's agreements in a relationship preserving manner"; Interaction manipulate mode: "The persistent efforts of an organization to act regardless of the ideas and preferences of its counterpart. It tries to shape, change or redefine the counterpart's actions or the situation by overpowering its counterpart"; Interaction avoid mode: "An organization's lack of intention to react to the action of a counterpart or situation"; Interaction defy mode: "An organization's dismissal of a counterpart's action or situation. It may either try to benefit from the relationship at the expense of its counterpart's interests, or it ends the relationship".

Another aspect is the locale the interaction takes place in. We identified two dimensions relevant for our research based on Camarinha-Matos and Afsarmanesh [19], namely Endogenous - Interactions that lie within the CNO-network, and Exogenous Interactions between actors outside the CNO-network. Additionally, we see a difference between synchronous and asynchronous communication [32], classified in our study as "time."

Clark et al. [32] indicate that there are three types of goals an actor tries to accomplish with an interaction. These are Consensual: Both Actors are in agreement; Responsive: An actor expects an answer from another actor; Elaborative: Interaction between two actors until the goal is reached. While the study focuses on student interaction, we think these types of goals can help understand the dynamics within CNOs and their interaction patterns.

Wagner, Beimborn, and Weitzel [33] describe the common human (H) / computer (C) communication model. This model describes the transfer of knowledge between two parties where the combination can be $\mathrm{H}-\mathrm{H}, \mathrm{H}-\mathrm{C} / \mathrm{C}-\mathrm{H}$, and C-C. These combinations need to be facilitated in knowledge transfer. We define $\mathrm{H}-\mathrm{H}$ interaction as a biological interaction, $\mathrm{H}-\mathrm{C} / \mathrm{C}-\mathrm{H}$ as a formal interaction, and $\mathrm{C}-\mathrm{C}$ as a technical interaction. Within our study, this component is called "Structures."

The level of formality is also a component we see that influences the interaction pattern. We combined these communication models with formal and informal levels where formal communication follows specific guidelines and has lower sequential variety, and informal communication is more ad hoc and has a higher sequential variety [34].

These components provide the ability to the framework to gather data about the way a relation is used, how they react to dynamism, and how this influences IT-needs.

\subsection{Framework}

The described themes provided a framework to structure and analyze the cases for our study. The framework is meant to provide a basis to discuss IT-needs in relation to dynamism in CNOs. The framework components can be viewed in Table 3. 
Table 3. Network dynamics framework

\begin{tabular}{|c|c|}
\hline \multicolumn{2}{|l|}{ Theme CNO } \\
\hline CNO goal & {$[35$} \\
\hline CNO type (horizontal, vertical) & {$[24]$} \\
\hline $\begin{array}{l}\text { CNO life cycle (initiation, foundation, operation, evolution, metamorphosis, } \\
\text { dissolution phase) }\end{array}$ & {$[35]$} \\
\hline \multicolumn{2}{|l|}{$\begin{array}{ll}\text { Theme relation } \\
\end{array}$} \\
\hline Trust (competence, relational, contractual trust) & {$[24]$} \\
\hline Entity role (hub, contact point) & {$[1]$} \\
\hline Relation type (direct tie, indirect tie, structural gap, tie value) & {$[16,26,31]$} \\
\hline Tie form (formal, informal tie) & {$[27,36$} \\
\hline Tie strength (strong, weak tie) & {$[27,30]$} \\
\hline Embeddedness (strong, weak embeddedness) & {$[27]$} \\
\hline \multicolumn{2}{|l|}{ Theme interaction } \\
\hline $\begin{array}{l}\text { Interaction mode (interaction create, interaction acquiesce, interaction com- } \\
\text { promise, interaction manipulate, interaction avoid, interaction defy mode) }\end{array}$ & {$[31]$} \\
\hline Locale (endogenous, exogenous) & {$[19$} \\
\hline Time (synchronous, asynchronous) & {$[32]$} \\
\hline Goal of interaction (consensual, responsive, elaborative) & {$[32]$} \\
\hline Structures (biological, formal, technical) & {$[17,33]$} \\
\hline Levels of formality (formal, informal) & {$[34]$} \\
\hline
\end{tabular}

\section{$5 \quad$ Case Study Results}

\subsection{Organizations}

This case study comprises four CNOs with a network size ranging from 4 to $50+$ participants. The CNOs have an ITSM focus and, at a minimum, one party has extensive IT knowledge in the ITSM project space.

CNO 1 and 2 show a vertical topology; $\mathrm{CNO} 4$ shows a horizontal topology. CNO 3 shows both types. $\mathrm{CNO}$ goals were related to providing a service, ranging from IT consolidation to project management. In total, 12 organizations participating in one of the four CNOs took part, resulting in 15 interviews spread over the organizations.

\subsection{Case Study Results}

During the analyses, the components most related to IT-needs and dynamics were CNO life cycle, interaction mode, and interaction structure, followed by trust, relation type, time, and level of formality. The least found components were entity role, CNO goal, $\mathrm{CNO}$ type, and locale. We did not see any influence by $\mathrm{CNO}$ goal and $\mathrm{CNO}$ type and 
therefore these components are omitted from the results. Only CNO life cycle was used for theme CNO. The identified IT-needs are listed in Table 4.

Table 4. Identified IT-needs

\begin{tabular}{llll}
\hline T1 & Collaboration tooling & T5 & Process support tooling \\
\hline T2 & Document templates & T6 & Knowledge sharing \\
\hline T3 & Task management tooling & T7 & Documentation tooling \\
T4 & Conference facilities & T8 & Forum \\
\hline
\end{tabular}

The IT-needs are mapped to the components of the framework (vertical axis) and the CNOs (horizontal axis) (Table 5). Each component describes the high-level findings.

Table 5. High-level results per $\mathrm{CNO}$

\begin{tabular}{|c|c|c|c|c|c|}
\hline & CNO 1 & CNO 2 & CNO 3 & CNO 4 & Needs \\
\hline \multicolumn{6}{|c|}{ Theme CNO } \\
\hline $\begin{array}{l}\text { CNO } \\
\text { life cy- } \\
\text { cle }\end{array}$ & $\begin{array}{l}\text { Evolution de- } \\
\text { creased dy- } \\
\text { namics. }\end{array}$ & $\begin{array}{l}\text { Evolution in- } \\
\text { creased dynamics. }\end{array}$ & $\begin{array}{l}\text { All phases } \\
\text { were recog- } \\
\text { nized. }\end{array}$ & $\begin{array}{l}\text { All phases } \\
\text { except dis- } \\
\text { solution. }\end{array}$ & $\begin{array}{l}\text { T1, T3, } \\
\text { T4, T5 }\end{array}$ \\
\hline \multicolumn{6}{|c|}{ Theme relation } \\
\hline Trust & $\begin{array}{l}\text { Competence } \\
\text { and relational. } \\
\text { Informal com- } \\
\text { munication } \\
\text { increased } \\
\text { trust. }\end{array}$ & $\begin{array}{l}\text { Contractual and } \\
\text { after evolution } \\
\text { competence and } \\
\text { relational. }\end{array}$ & $\begin{array}{l}\text { Relational. } \\
\text { Minimalistic } \\
\text { agreements, } \\
\text { high amount } \\
\text { of trust. }\end{array}$ & $\begin{array}{l}\text { Compe- } \\
\text { tence, con- } \\
\text { tractual. }\end{array}$ & $\begin{array}{l}\text { T1, T3, } \\
\text { T4 }\end{array}$ \\
\hline $\begin{array}{l}\text { Entity } \\
\text { role }\end{array}$ & $\begin{array}{l}\text { Hub, contact } \\
\text { point. }\end{array}$ & Hub & $\begin{array}{l}\text { Hub, contact } \\
\text { point. }\end{array}$ & Hub & $\begin{array}{l}\text { T1, T4, } \\
\text { T6 }\end{array}$ \\
\hline $\begin{array}{l}\text { Relation } \\
\text { type }\end{array}$ & Direct & $\begin{array}{l}\text { Indirect, after } \\
\text { evolution direct. }\end{array}$ & Direct & Direct & $\begin{array}{l}\text { T1, T3, } \\
\text { T4, T5 }\end{array}$ \\
\hline Tie form & $\begin{array}{l}\text { Formal and } \\
\text { when dynam- } \\
\text { ics increased, } \\
\text { informal. }\end{array}$ & $\begin{array}{l}\text { Formal and after } \\
\text { evolution infor- } \\
\text { mal. }\end{array}$ & Informal & Formal & $\mathrm{T} 1, \mathrm{~T} 4$ \\
\hline $\begin{array}{l}\text { Tie } \\
\text { strength }\end{array}$ & Strong & $\begin{array}{l}\text { Weak and after } \\
\text { evolution strong. }\end{array}$ & Strong & Strong & $\begin{array}{l}\text { T1, T4, } \\
\text { T6 }\end{array}$ \\
\hline $\begin{array}{l}\text { Embed- } \\
\text { dedness }\end{array}$ & Strong & $\begin{array}{l}\text { Weak, decreased } \\
\text { dynamics, created } \\
\text { misalignment, } \\
\text { lowered trust. }\end{array}$ & Strong & Weak & $\mathrm{T} 1, \mathrm{~T} 4$ \\
\hline \multicolumn{6}{|c|}{ Theme interaction } \\
\hline $\begin{array}{l}\text { Interac- } \\
\text { tion } \\
\text { mode }\end{array}$ & $\begin{array}{l}\text { Acquiesce, } \\
\text { create. }\end{array}$ & $\begin{array}{l}\text { Avoid and manip- } \\
\text { ulate to gain a } \\
\text { dominant role and } \\
\text { increase trust. }\end{array}$ & $\begin{array}{l}\text { Compromise, } \\
\text { Acquiesce and } \\
\text { create. }\end{array}$ & $\begin{array}{l}\text { Acquiesce, } \\
\text { create. }\end{array}$ & $\begin{array}{l}\text { T1, T2, } \\
\text { T3, T4 }\end{array}$ \\
\hline
\end{tabular}




\begin{tabular}{|l|l|l|l|l||l|}
\hline Locale & Exogenous & Exogenous & Endogenous & $\begin{array}{l}\text { Endogenous } \\
\text { and exoge- } \\
\text { nous. }\end{array}$ & $\begin{array}{l}\text { T1, T4, } \\
\text { T8 }\end{array}$ \\
\hline Time & Synchronous & $\begin{array}{l}\text { Asynchronous } \\
\text { and moved to syn- } \\
\text { chronous. }\end{array}$ & $\begin{array}{l}\text { Asynchronous } \\
\text { at initiation. } \\
\text { Moved to syn- } \\
\text { chronous. }\end{array}$ & $\begin{array}{l}\text { Endoge- } \\
\text { nous: syn- } \\
\text { chronous. } \\
\text { Exogenous: } \\
\text { asynchro- } \\
\text { nous. }\end{array}$ & $\begin{array}{l}\text { T1, T3, } \\
\text { T4, T5 }\end{array}$ \\
\hline $\begin{array}{l}\text { Goal of } \\
\text { interac- } \\
\text { tion }\end{array}$ & $\begin{array}{l}\text { Consensual, } \\
\text { responsive, } \\
\text { elaborative. }\end{array}$ & $\begin{array}{l}\text { Consensual, re- } \\
\text { sponsive, elabora- } \\
\text { tive. }\end{array}$ & $\begin{array}{l}\text { Consensual, } \\
\text { responsive. }\end{array}$ & Elaborative & $\begin{array}{l}\text { T1, T2, } \\
\text { T4, T5 }\end{array}$ \\
\hline $\begin{array}{l}\text { Struc- } \\
\text { tures }\end{array}$ & $\begin{array}{l}\text { Biological } \\
\text { and later for- } \\
\text { mal and tech- } \\
\text { nical. }\end{array}$ & $\begin{array}{l}\text { Technical at the } \\
\text { beginning and } \\
\text { then biological. }\end{array}$ & $\begin{array}{l}\text { Biological and } \\
\text { formal. }\end{array}$ & $\begin{array}{l}\text { Biological } \\
\text { and formal. }\end{array}$ & $\begin{array}{l}\text { T1, T3, } \\
\text { T4, T5 }\end{array}$ \\
\hline $\begin{array}{l}\text { Levels } \\
\text { of for- } \\
\text { mality }\end{array}$ & $\begin{array}{l}\text { Informal. } \\
\text { Later formal- } \\
\text { ity increased } \\
\text { due to tooling. }\end{array}$ & $\begin{array}{l}\text { Formal with goal } \\
\text { to increase trust. } \\
\text { After increase, in- } \\
\text { formal to increase } \\
\text { dynamics. }\end{array}$ & $\begin{array}{l}\text { Informal, } \\
\text { which pro- } \\
\text { vided a basis } \\
\text { to cope with } \\
\text { dynamics. }\end{array}$ & $\begin{array}{l}\text { Formal and } \\
\text { informal. }\end{array}$ & $\begin{array}{l}\text { T1, T2, } \\
\text { T3, T4, } \\
\text { T8 }\end{array}$ \\
\hline $\begin{array}{l}\text { IT-needs } \\
\text { T1, T2, T3, }\end{array}$ & $\begin{array}{l}\text { T1, T3, T5 } \\
\text { T4 }\end{array}$ & $\begin{array}{l}\text { T1, T3, T5, } \\
\text { T6 }\end{array}$ & $\begin{array}{l}\text { T1, T3, T7, } \\
\text { T8 }\end{array}$ & \\
\hline
\end{tabular}

From the case study, we confirmed that IT is crucial to facilitate collaboration for a CNO. Collaboration tooling (T1) and conference facilities (T4) are mentioned frequently as an IT-need related to the majority of the framework components. The components trust, relation type, embeddedness, and time were also discussed frequently. IT-needs T1 and T4 were mentioned to increase trust, facilitate direct relations, strong embeddedness, and (a)synchronous communication. T1 is not only focused on office tooling but also a shared environment for specific tools used within the CNO. An example is 3D drawing tools. The intensity for the IT-need T4 increases when there are direct and strong ties as opposed to only providing and using $\mathrm{T} 1$ as a shared environment (relation type and tie strength). When participants in the network work on different components of an assignment, defining used tooling and collaborating via T1 is extended by integrating the work to a combined result during the creation of a product.

When discussing trust, interviewees mentioned that when competence and relational trust increases, informal ties, strong embeddedness, and synchronous interaction in a biological structure is preferred. $\mathrm{T} 1, \mathrm{~T} 3, \mathrm{~T} 4$, and $\mathrm{T} 5$ were mentioned as IT-needs related to these components. Contractual trust (mainly in the initial life cycle phase) did also trigger the IT-need for T1 and T4 to facilitate collaboration.

When discussing how CNOs cope with dynamics, informal ties and an informal level of formality were mentioned. The related IT-needs were T1, T3 and T4.

Interviewees did not mention technical communication structure to cope with dynamics. Within the cases, tooling was used to optimize processes between participants 
(T5), and in the evolvement of the $\mathrm{CNO}$ more tooling was introduced to optimize biological, formal, and technical communication.

Indirect relations were also recognized and it was mentioned that the collaboration relied on email and in some cases T3 and T5.

Exogenous relations were mentioned to be supported by asynchronous communication and facilitated by $\mathrm{T} 5$ and $\mathrm{T} 8$. When the interaction in exogenous relations increases, T1 and T4 were mentioned as an IT-need to cope with dynamics.

Overall, we can see that when interaction increases (which in the cases is related to increased dynamics) the move to more "active" relations and interaction patterns are visible. These increased communication paths are then supported mostly by T1 and T4, sometimes by T2, T3 and T5 and in some cases T6 and T7. T8 (Forum) is often seen as a method to cope with asynchronous, indirect communication, and exogenous relations.

\section{Discussion, Limitations, and Future Research}

In this section, we will discuss IT-needs within CNOs to cope with CNO-dynamism.

The interviewees recognized all components in the model, which validates the model we created. The framework was not extended based on the result. We got valuable information about IT-needs of CNOs and the IT-needs to cope with dynamics.

When the relationship and interaction were exogenous and formal, and the tie strength was weak, the communication regularly was asynchronous via email or a forum (T8). In some cases, supported via supportive systems (T5). When the relationship and interaction moved to tie strength strong, tie form informal and embeddedness was high. Moreover, T1 and T4 were mentioned as an IT-need. When dynamics are introduced in a $\mathrm{CNO}$, the interviewees indicated a preference for synchronous, informal communication in a biological and formal structure, resulting in the need for T1 and $\mathrm{T} 4$. We cannot state that dynamism forces $\mathrm{T} 1$ and $\mathrm{T} 4$ or if dynamism forces active interaction and therefore the need for T1 and T4. Still, the need to cope with dynamism triggers the IT-need for the collaborative environment (T1) and conference facilities (T4).

The IT-need for task management tooling (T3) was mentioned in relation to dynamics related to trust, relation type, interaction mode, time, and structure within all CNOs. When dynamics occur, the number of tasks to execute increased and tooling that supports that was needed. The IT-needs document templates (T2), knowledge sharing (T6), and documentation tooling (T7) were not mentioned related to dynamics, and thus we think that these are not used to cope with dynamics within the CNO.

IT-needs did not drastically change related to the $\mathrm{CNO}$ life cycle. Dynamics cannot be planned and therefore facilitating a collaborative environment (T1), task management tooling (T3), and conference facilities (T4) from the beginning of the CNO could be part of general requirements.

The topic of technical structures was not frequently addressed and did not result in an IT-need. We expected this to be a more prominent topic especially with the ITSM 
focus within the CNOs. Technical structures were mentioned as a possible improvement for the CNO. The lack of technical structures could be related to the goal-oriented focus of the CNOs within our study.

Our model could be extended by different research fields. For instance, media synchronicity [37] could provide more insight into biologic communication from a process perspective differentiated in a conveyance and convergence stage, to in the end, tailor it to the CNOs specific need. Also, electronic negotiation [38] could be used to facilitate technical communication, still this was not specifically mentioned as a method to cope with dynamism within our study.

Overall, we noticed that trust was a central and important topic within our interviews. Trust (specifically competence and relational) was mentioned combined with other characteristics like a direct relation type, strong ties, and a high amount of communication (biological). Leading to strong relations. The component-time and locale were often mentioned together. Mainly in the combination of asynchronous/exogenous and synchronous/endogenous. All IT-needs are, as expected, related to collaboration and interaction. When discussing dynamics mainly IT-needs T1, T3, and T4 were mentioned. Mostly in the context of increased informal and synchronous communication.

In this study, we focused on the relationship between participants and not all "dynamic and self-regulating" characteristics. Our characteristics are on an operational level, where others are related to strategy (landscape of organizations) or governance topic (dynamic partnering, maturity). We expect that analyzing the other characteristics will be useful. Also, the lack of technical structures was not expected. We do not know why these technical structures were not present, but we would have expected that these structures would be an IT-need to cope with dynamism in a prosperous CNO. These points show room for future research.

These results can help practitioners in determining the needed IT systems when participating in a collaborative organization so that they are prepared to cope with the dynamism they could encounter as a CNO. From a research perspective, these results provide more insight into IT-needs that help cope with the dynamism CNOs can encounter. Within our broader research program, we will try to create guidelines and hopefully a new BITA model that could facilitate CNOs and specifically their operational BITA between the participants that take part in the CNO. To in the end provide a model that is more suitable for these networked organizations with their vast number of configurations, and fill a gap within the body-of-knowledge on this topic.

Our study does have some limitations that future research should seek to address. First, our SLR and thus our framework finds it basis in the paper of Camarinha-Matos and Afsarmanesh [2] where they introduce the scientific discipline around CNOs. We tried to keep our search queries as broad as we can, but the concept of CNO is part of our search queries. By using backward searching we broadened our scope, still could have limited our SLR, our framework, and thus our results. Second, dynamism is a phenomenon that changes over time. Our research was cross-sectional and thus replicating the study over time could gather more valuable insights. Third, CNOs consist of and are formed by multiple participants. The vast number of configurations a $\mathrm{CNO}$ can have based on capabilities, the configuration of the participant, and other characteristics create complex objects to analyze [39]. We gather results within our study and agree 
that generalization based on these configurations is hard. By using common aspects of the CNOs, like goals and type of participants within a CNO, we tried to limit this effect. Still, we think that multiple studies will result in valuable additional data to research this topic. Last, by using transcribed interviews, intensive coding frameworks, and cross-referencing the codes between the interviewers, we tried to limit observer bias; however, we cannot guarantee that no bias entered the research. We do think we mitigated this risk adequately by applying a rigorous method of coding and analyses based on theory from Yin [40] and adding validation from external researchers.

\section{Conclusion}

By following an explicit research methodology we derived results regarding IT-needs in CNOs having to cope with dynamism.

First, collaboration tooling (T1), document templates (T2), task management tooling (T3), conference facilities (T4), process support tooling (T5), knowledge sharing (T6), documentation tooling (T7) and a forum (T8) are IT-needs within a CNO.

Second, collaboration tooling (T1), task management tooling (T3), and conference facilities (T4) are IT-needs to cope with CNO-dynamism. T1, T3, and T4 facilitate informal, synchronous, biologic communication that is mentioned as a preferred method of interaction to cope with dynamism. Third, when trust is lacking, informal and faceto-face communication is mentioned as a method to increase trust, which can be facilitated via the IT-need T1, T3, and T4. Last, we notice that technical structures were not mentioned as an IT-needs.

Via a rigorous research process; creating a framework via systematic literature reviews and using this framework in our multi case study in four CNOs (15 interviews over 12 organizations), coding the results and validating these codes, we succeeded in identifying IT-needs that are used to cope with the dynamics a CNO encounters. Our results can help CNOs determine their IT-needs upfront and the framework could help CNOs to identify their IT-needs. Scientifically we extended the body-of-knowledge with more insights in IT-needs to cope with CNO-dynamism.

Acknowledgments: This paper was created with the help of Manon van Rooijen van der Bas, Merel Visser, and Danny van Maanen.

\section{References}

1. Grefen, P., Mehandjiev, N., Kouvas, G., Weichhart, G., Eshuis, R.: Dynamic business network process management in instant virtual enterprises. Computers in Industry 60(2), 86103 (2009).

2. Camarinha-Matos, L.M., Afsarmanesh, H.: Collaborative networks: a new scientific discipline. Journal of Intelligent Manufacturing 16(4-5), 439-452 (2005).

3. Grefen, P.: Networked business process management. International Journal of IT/Business Alignment and Governance (IJITBAG) 4(2), 54-82 (2013).

4. Coltman, T., Tallon, P., Sharma, R., Queiroz, M.: Strategic IT alignment: twenty-five years on. Journal of Information technology 30(2), 91-100 (2015). 
5. Bernus, P., Noran, O., Molina, A.: Enterprise architecture: Twenty years of the GERAM framework. Annual Reviews in Control 39, 83-93 (2015).

6. Van den Heuvel, R., Trienekens, J., Van de Wetering, R., Bos, R.: Business/IT-alignment adaptation in dynamic networked environments. In: PRO-VE2016, Porto, Portugal (2016).

7. Cuenca, L., Boza, A., Ortiz, A., Trienekens, J.J.M.: Business-IT Alignment and Service Oriented Architecture - A Proposal of a Service-Oriented Strategic Alignment Model. In: Hammoudi, S., Cordeiro, J.,Maciaszek, L. (eds.) Proceedings of the 16th International Conference on Enterprise Information Systems (ICEIS 2014). vol. 3, pp. 490-496. SCITEPRESS-Science and Technology Publications, Lda., (2014).

8. Van den Heuvel, R., Trienekens, J., Van de Wetering, R., Bos, R.: Toward CNO Characteristics to Support Business/IT-Alignment. In: Camarinha-Matos, L.M., Afsarmanesh, H.,Fornasiero, R. (eds.) Collaboration in a Data-Rich World. PRO-VE 2017. IFIP Advances in Information and Communication Technology, vol. 506, pp. 455-465. Springer, Cham, (2017).

9. Walters, D., Buchanan, J.: The new economy, new opportunities and new structures. Management Decision 39(10), 818-834 (2001).

10. Camarinha-Matos, L.M., Afsarmanesh, H., Galeano, N., Molina, A.: Collaborative networked organizations - Concepts and practice in manufacturing enterprises. Computers \& Industrial Engineering 57(1), 46-60 (2009).

11. Concha, D., Espadas, J., Romero, D., Molina, A.: The e-HUB evolution: From a Custom Software Architecture to a Software-as-a-Service implementation. Computers in Industry 61(2), 145-151 (2010).

12. Henderson, J.C., Venkatraman, N.: Strategic alignment: Leveraging information technology for transforming organizations. IBM systems journal 32(1), 472-484 (1993).

13. Luftman, J.: Assessing Business-IT Allignment Maturity, In: Strategies for information technology governance, IGI Global: Hershey, PA (2004).

14. Bagheri, S., Kusters, R.J., Trienekens, J.J.M.: Business-IT Alignment in PSS Value Networks-Linking Customer Knowledge Management to Social Customer Relationship Management. In: Hammoudi, S., Cordeiro, J.,Maciaszek, L. (eds.) Proceedings of the 17th International Conference on Enterprise Information Systems (ICEIS 2015). vol. 3, pp. 249257. SCITEPRESS-Science and Technology Publications, Lda., (2015).

15. Parmigiani, A., Rivera-Santos, M.: Clearing a Path Through the Forest: A Meta-Review of Interorganizational Relationships. Journal of Management 37(4), 1108-1136 (2011).

16. Ahuja, G.: Collaboration networks, structural holes, and innovation: A longitudinal study. Administrative Science Quarterly 45(3), 425-455 (2000).

17. Jaakkola, H., Henno, J., Thalheim, B., Mäkelä, J.: Collaboration, distribution and culturechallenges for communication. In: 38th International Convention on Information and Communication Technology, Electronics and Microelectronics (MIPRO), pp. 657-664. IEEE, Opatija, Croatia (2015).

18. Camarinha-Matos, L.M.: Collaborative networked organizations: Status and trends in manufacturing. Annual Reviews in Control 33(2), 199-208 (2009).

19. Camarinha-Matos, L.M., Afsarmanesh, H.: A comprehensive modeling framework for collaborative networked organizations. Journal of Intelligent Manufacturing 18(5), 529-542 (2007).

20. Saunders, M., Lewis, P., Thornhill, A.: Research Methods for Business Students. 7th ed. Pearson Education Limited, Harlow (2016).

21. Scientific Software Development GmbH: ATLAS.ti (8.2). Berlin, Germany, http://www.atlasti.com/ (2018). 
22. Boudreau, M.-C., Gefen, D., Straub, D.W.: Validation in information systems research: a state-of-the-art assessment. MIS quarterly, 1-16 (2001).

23. Camarinha-Matos, L.M., Afsarmanesh, H.: Taxonomy of collaborative networks forms: FInES Task Force on Collaborative Networks and SOCOLNET - Society of Collaborative Networks, In: Roots and Wings, European Commission (2012).

24. Cheikhrouhou, N., Pouly, M., Madinabeitia, G.: Trust categories and their impacts on information exchange processes in vertical collaborative networked organisations. International Journal of Computer Integrated Manufacturing 26(1-2), 87-100 (2013).

25. Camarinha-Matos, L.M., Afsarmanesh, H.: Collaborative networks: Reference modeling. Springer Science+Business Media, LLC, New York (2008).

26. Osman, L.H.: The Pattern of Inter-Organizational Level of Connectivity, Formal Versus Informal Ties. Jurnal Komunikasi, Malaysian Journal of Communication 33(1), 59-79 (2017).

27. Wulf, A., Butel, L.: Knowledge sharing and collaborative relationships in business ecosystems and networks. Industrial Management \& Data Systems 117(7), 1407-1425 (2017).

28. Caimo, A., Lomi, A.: Knowledge sharing in organizations: A Bayesian analysis of the role of reciprocity and formal structure. Journal of Management 41(2), 665-691 (2015).

29. Franco, M., Haase, H.: Inter-organizational cooperation in community health organizations: a competence-based perspective. International journal of health care quality assurance $28(2)$, 193-210 (2015).

30. Levin, D.Z., Cross, R.: The Strength of Weak Ties You Can Trust: The Mediating Role of Trust in Effective Knowledge Transfer. Management Science 50(11), 1477-1490 (2004).

31. Oukes, T., Raesfeld von, A.: A start-up in interaction with its partners. IMP Journal 10(1), 50-80 (2016).

32. Clark, D.B., Sampson, V., Weinberger, A., Erkens, G.: Analytic Frameworks for Assessing Dialogic Argumentation in Online Learning Environments. Educational Psychology Review 19(3), 343-374 (2007).

33. Wagner, H.-T., Beimborn, D., Weitzel, T.: How Social Capital Among Information Technology and Business Units Drives Operational Alignment and IT Business Value. Journal of management information systems 31(1), 241-272 (2014).

34. Becker, M.C.: A framework for applying organizational routines in empirical research: linking antecedents, characteristics and performance outcomes of recurrent interaction patterns. Industrial and Corporate Change 14(5), 817-846 (2005).

35. Camarinha-Matos, L.M., Afsarmanesh, H.: On reference models for collaborative networked organizations. International Journal of Production Research 46(9), 2453-2469 (2008).

36. Grant, R.M., Baden-Fuller, C.: A Knowledge Accessing Theory of Strategic Alliances. Journal of Management Studies 41(1), 61-84 (2004).

37. Dennis, A.R., Valacich, J.S.: Rethinking media richness: towards a theory of media synchronicity. In: Proceedings of the 32nd Annual Hawaii International Conference on Systems Sciences, pp. 1-10. IEEE, Maui, HI, USA (1999).

38. Bichler, M., Kersten, G., Strecker, S.: Towards a Structured Design of Electronic Negotiations. Group Decision and Negotiation 12(4), 311-335 (2003).

39. Van de Wetering, R., Mikalef, P., Helms, R.: Driving organizational sustainability-oriented innovation capabilities: a complex adaptive systems perspective. Current opinion in environmental sustainability 28, 71-79 (2017).

40. Yin, R.K.: Case Study Research: Design and Methods. 5th ed. SAGE Publications, Los Angeles (2014). 